\title{
Formation of Knowledge of Causes of Infectious Diseases and Development of Specific Prevention against them in Hungary from the Beginning till 1900
}

\section{Ralovich Béla*}

Ministry of Welfare (Retired), Budapest, Hungary

*Corresponding Author: Ralovich Béla, 8649 Balatonberény, Rozmaring utca 13. Hungary.

Received: March 01, 2018; Published: March 27, 2018

DOI: $10.31080 /$ ASMI.2018.01.0043

\section{The origin of the Hungarian Nation}

On the basis of the genetic studies of Czeizel Endre (2003) ancestors of the Hungarian people originated from Asia behind Mountain Ural from the Ural-Altaic Family which was formed around 6 - 4 thousand years B.C. Our ancestors left that early home towards the south where they were mixed with ancient Persian tribes (Sarmatians, Turkic people and so on). They got not only new genes from them but culture (runic letters) also. From there they went into "Magna Hungaria" before Ural approx. 1000 B.C. The early Hungarian Tribes were formed there. Around 460 A.C. they went into Levedia and latter arrived at Etelköz. Durin that way since 500 A.C. connections had been formed with Byzantium which lasted for centuries (till around 1200). In consequence of this the East-Roman Catholic/Byzantine monks appeared among us. Finally Prince Árpád (845-907) had led our tribes from Etelköz into Carpathien Basen at the end of 800 A.C.

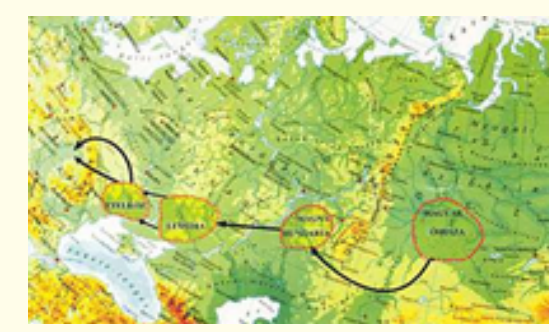

Figure 1: The origin of the Hungarian Nation.

\section{Short history of our educational system}

In the early periods of time shamans/wizards might perform religious and medical services for our population who were admirers of Nature. That time professional knowledge spread from fathers to sons. Since 500 A.C. Byzantine monks have lived with us and their religion as well as their classic knowledge have affected mentality and life of our people. In the Carpathien Basen first Árpád's grand child Prince Taksony (955-970) met Benedictine monks and later on Prince Géza (972-997) invited them into our country to live with us and to teach our population. Around 1000 they started to build their monasteries (together with xenodochia/hostels, cloister pharmacies and started to grow herbs for medical use). They not only thought but did medical services, too. Our first King I. St. Stephen (997-1038) supported building of churches, cathedrals as well as monasteries and ordered all inhabitants to go into them on each Sunday. Services in these places were performed first Slavonic and later Hungarian language. The bishops who were highly educated persons played important role in the state policy, too. The xenodochia/hostels (the number of which was about 75 between 1000-1400) were progenitors of our latter hospitals. Besides these leprosariums also existed. The monks taught in schools of monasteries and that of parish churches (of village or town, their total number had become 275 from 1000 till 1540). In the same time 15 cloister schools/academia capitularis were also built near cathedrals in which teaching of high level happened. In that period of time teaching mainly served production of monks/priests. The language of that teaching was Latine and the system was the same as in the other West-European countries. Our first University/ Studium Generale was founded by King III. Béla in Veszprém between 1172 and 1196 after the University of Montpellier and that of Bologna. King III. Béla was educated in Byzantium. This University was approved by Pope IV. Innocent. It was destroyed at the end of 1270. After that we had Dominican Studium Generale in Buda (1305-1541) and Nagyszeben (1525-1532); "state” University (organized by the king and a bishop and approved by the Pope) in Pécs (1367-1543), Buda (1389-1437), Pozsony (1465-1471) and Kolozsvár (1582). After Tartar's rage (1242) the Turkish occupation has started in 1524 and lasted for 150 years. In 1527 the first protestant school/college was organized in Sárospatak and later more were also built. Their mentality brought new colour into our education. As a result of this process the Protestant Academy/ University of Gyulafehérvár (1622-1658) was opened and after its demolition a College was organized in Nagyszeben (1664-1896) to continue teaching. Cardinal Oláh Miklós reformed the Roman Catholic education and invited Jesuits into our country in 1561. Their role which lasted for abour 200 years was very important. Latter an University was organized at Eger in 1769, but its life was very short. The first permanent University (the origin of which was a prist-training Hight School founded between 1555-58) with two Faculties was organized by Cardinal Pázmány Péter at Nagyszombat in 1635 which was developed and transported to Buda (1777) and from there to Pest (1784). This University has existed in Budapest at present, too. Besides the before mentioned educational institutions we had also Jesuitical and after nationalization Royal Academies, Benedictine and Protestant High Schools, private medical and agricultural schools and a horticultural school, too. 


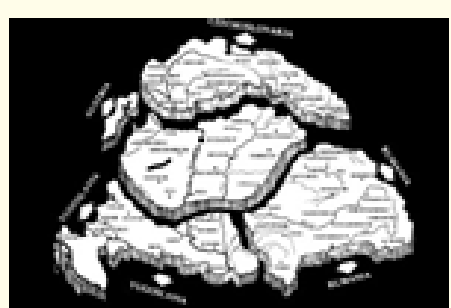

Figure 2: Consequences of Trianon Peace-Treaty.

After the World War I in consequence of the brutal Trianon Peace-Treaty we lost $66 \%$ of our territory together with our different educational and other institutions as well as $32 \%$ of our population, too.

Birth of magnifiers, microscopes and microbiology

If the old classic data have been excluded then the English monk Rogerius Bacon discovered the first magnifier in 1276. Since that date lens/looking-glasses have been used. Members of the family of Janssen made the first microscopes at the end of XVI ${ }^{\text {th }}$ century. After them R. Hooke, N. Grew, M. Malphigi, A. van Leeuwenhoek and others reported about their better microscopes and examinations. Discovery of "micro-world" has started. (For example: Hooke saw productive bodies of moulds and fossils of protozoa; Leeuwenhoek realized "animacula"; P. A. Micheli dealt with cryptogams, microfungi and sporos. M. du Tillet discovered the cause of black-rust of grains and the first bacterium V. lineola was described by O. F. Müller in 1775 and so on. These discoveries gave the base of microbiology).

\section{Definition of microbiology}

"Microbiology is an inter-disciplinary basic science, a part of the biology which involves all knowledge collected by bacteriologists, virologists, mykologists, geneticists, molecular biologists as well as those persons who deal with special species of plants and animals that is botanists and zoologists further by other specialists with the help of microscopes, submicroscopic, molecular and other technics and methods. The objects of the investigations listed above are: proteins (prions), nucleic acids (viroids, plasmids), viruses and phages, prokaryotes (cultivable or non-cultivable bacteria), eukaryotes that is unicellular plants (algae), animals (protozoa) and moulds" [1-3].

\section{Data to the teaching of natural sciences in Hungary}

Teaching of subjects of "natural sciences" started with presentation of seven free arts on the basis of Aristotelian physics together with the Bible in the schools. The first Hungarian teaching book entitled "Deliberatio..." was written by hand in Latine by Bishop St. Gellért around 1040. He thought in the cloister school of Csanád. One copy of his book which was used in Europa, too, can be seen in the Museum of Munich. Later these subjects were thought in different degree not only in our universities but also in some of our other educational institutions
In the XVIII ${ }^{\text {th }}$ century King III. Charles, Queen Maria Theresia, King II. Joseph and King I. Francis supported the progress, nationalized education and ordered teaching of natural sciences on all level. They founded schools for mining (1735), technology (1763) as well as forestry (1770) and organized Medical Faculty (1770) besides different institutes for agriculture (1777), technology (1782) and veterinary (1787) on Nagyszombat/Buda/Pest University and also a Veterinary Institute at Kolozsvár on the MedicalSurgical High School (1787), too. Later new universities were also founded in Kolozsvár (1872), Pozsony (1912), Debrecen (1914) and so on.

At the beginning on Nagyszombat University botanical, zoological, mineralogical and medical knowledge were taught together. These subjects became slowly independent from each other. After 1850 all of them were thought in separate institutes on the Faculty of Art or on the Medical Faculty. In 1783 on the Medical Faculty teaching of veterinary knowledge started for medical and surgical students. Later the Veterinary Institute and the new Institute of Animal Health (1790) became the base of our veterinary education. The Veterinary Institute was separated from the University in 1851 and as a "K.u.K. Thierärztney Institut" of Pest has started to live independently. Besides veterinary subjects were also taught on high level at different agricultural schools (Keszthely Georgicon from 1797, Mosonmagyaróvár High School from 1818, Kolozsvár High School from 1863 and so on). At the beginning horticulture was taught together with agriculture. Its independent teaching has started at Pest in 1853. The first Faculty of Natural Sciences was formed on Kolozsvár University in 1872 which was the 2nd such Faculty in Europe.

In Europe calendars have been used long ago. Before bookprinting (1455) they were written by hand. Calendars were prepared not only for religious purpose but they served education of people, too, as some of them contained more or less materials which were connected with the everyday life, agriculture, human and/or animal health, and so on. These calendars gave advice to treat diseases of human beings and animals mainly horses. The first Hungarian hand written calendar was made in 1190 and the first printed calendar was issued by Székely István in 1538 at Cracow. The first printed Hungarian medical text of a calendar which was written by Egyedúti Gergely came out at Vienna in 1572.

\section{Teaching and use of magnifiers and microscopes}

It is natural that magnifiers could only be used after 1276 in our country, too. In the "Lexicon" of Szenci Molnár Albert which was published in 1621 conspicillum word can be read. Its Hungarian meaning is ocular/looking-glass. The book entitled "Orbis Sensualium Pictus" was written at Sárospatak by J. A. Comenius in 1657 for students. He spoke not only from lens in Latine-GermanHungarian languages but their function was also demonstrated. Some persons (Lippay György (in 1650), Spilenberger Dávid (in 1684) had magnifier which later might also be found in some of so called "pharmacy boxes" which were used by priests and families. 
Around 1671 Paterson Hain János performed examinations with his self-made microscope in Eperjes. The first textbook entitled "Institutiones philosophiae naturalis..." was published by Tőke István in 1736 at Nagyenyed in which the picture of microscopes (See Figure 3) can be seen and about insects as well as animalcule can be read.

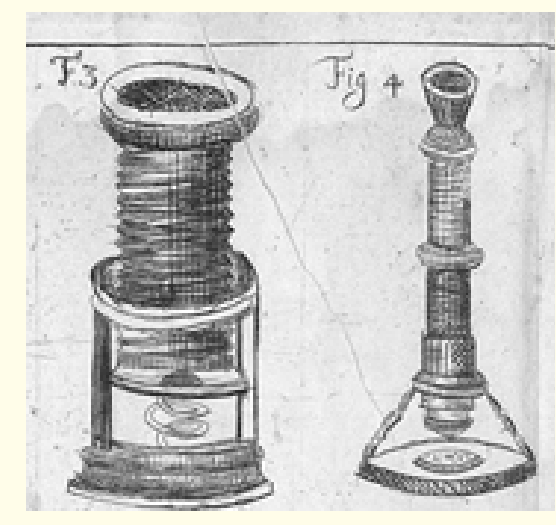

Figure 3: Picture of microscopes.

At present it is not known that the first microscope in which of our educational institutions was used. Perhaps Nagyszombat University or Nagyenyed College might be the first but one thing is sure that a Hooke's microscope has existed since 1671 in Sárospatak Protestan College (Figure 4). In the revised edition of "Dictionarium” of Pápai Páriz Ferenc in 1767 microscopium word is also present.

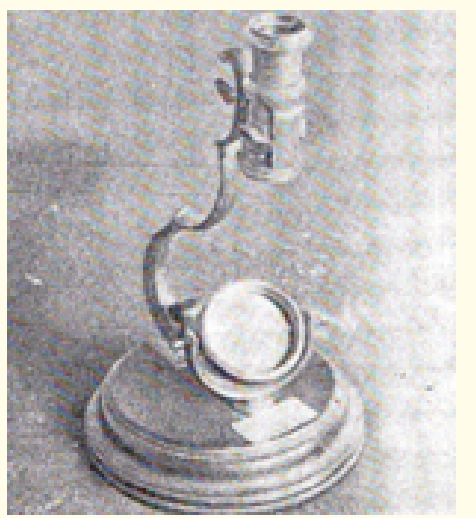

Figure 4: Hook's microscope.

\section{Historical data connected with the cause of infectious diseases}

In our country written informations about human illnesses could be first read in the Latine book of St. Gellért. Then the causes of illnesses were interpreted with the Greek theory on the basis of which dissolution of balance among different body fluids or astronomical events could cause diseases. Another theory was that God punished people with illnesses because of their sins. Later in consequence of the progress new opinions were born. G. Fracastoro wrote first in 1546 that contagium vivum was the cause of infectious diseases and he listed three forms of its transmission (direct, with an object and airborne). In 1628 W. Harvey published his famous sentence: "Omne vivum ex ovo". In 1659 A. Kircher stated that he saw "kleine Würmer" in the blood of plague patient. At present nobody knows what did he see. In 1668 F. Redi wrote in his book that the larvae in a putrid meat originated from the eggs of flies and they were not spontaneously born and Lazzaro Spallanzani that boiling killed the possibility of spontaneous birth in a medium. Finally M. A. von Plenciz who worked in Vienna published in 1762 that the "seeds" could cause infectious diseases. In spite of these opinions the original theories had widely survived for centuries.

\section{The cause of plague by Egyedúti Gergely}

But what was the situation in Hungary? Egyedúti Gergely wrote in his printed calendar in the Medical Chapter entitled "About pestiferous death and other illnesses" that "the cause of pestiferous death originated from the death of sky or its unlimited heat which resulted in great hot or humidity..."

Opinion of Kolozsvári Jordán Tamás about plague and syphilis

He published at least two books. Title of the first is "Pestis Phenomena seu..." which was printed in 1576 and the other entitled "Luis novae in Moravia" came out in 1580. In the first he dealt with the fevers and wrote that the cause of plague was the deteriorate of sky and infection. In connection with syphilis he recognized and published the first iatrogenic infection transmitted with a vacuum exhauster instrument (in Hungarian: köpölyöző and köpöly) used by a barber/chirurgic.

Sticker, poison and pestiferous substance of Lencsés György and Frankovith Gergely

Lencsés György wrote his big encyclopaedic book dealing with medicine and pharmacy in 1577 . He wrote that the feverish, pestilential illnesses were caused by pestiferous air, contaminated food or different other ways. Some years later in 1588 Frankovith Gergely edited his book. He dealt with infectious diseases. In connection with plague it can be read: “... But from whom and where sticks to that person who will be first ill because it starts on one man anywhere or in a city and spread to the others..." He knew that something which could spread and stick caused plague. In relation to medicines he wrote: "... the power of a good medicine is effective in the all body of a patient... and knocks the poison out from which plague can form... removes pestiferous substance, if the treatment was in time.... These ideas were important that time. Besides Frankovith interpreted the causes of unknown events with the will of God. This was no wander at all as he knew that every event had at least a cause and as there was not any knowledge about microorganisms he saw that in God.

Poison of Pápai Páriz Ferenc and his proposal for a diagnostic animal test

Pápai Páriz Ferenc who was a teacher in Nagyenyed College edited his very important book entitled "Pax corporis" in 1690. He wrote "... bite of a rabid or furious dog causes strange changes in the body of a human being in consequence of that the poison overcomes and results dread of water of the patient". All time it is important to be sure whether the dog is rabid or not. Therefore he proposed "... Crack a nut gently and fasten its kernel to the wound and wait for a time. Later give it to hen to eat and if it will die the dog was rabid. You can also try this verification with bread on the same way". "If the dog is rabid then it is necessary to put a vacuum exhauster on the wound to be sucked. The sucker sucks the blood together with the poison before it could be effective. If impossible to perform this treatment then it is necessary to burn the place of bite with hot iron sheet". 


\section{Rácz Sámuel from the cause of scarlet}

In 1784 Rácz Sámuel published about the cause of scarlet: "Plenciz thinks that special living seeds which can proliferate cause scarlet. These seeds can spread by wind faraway or sometimes they can survive in a body seemingly without life for a long time when suddenly they become active".

Bene Ferenc's opinion and that of Gebhardt Xavér Ferenc about smallpox

In 1800 Bene Ferenc wrote about variola. In his book the next sentences can be read: "Two conditions are necessary for variola disease; the first is the smallpox poison as a triggering cause; the second is the susceptibility of a body to the poison. The poison is produced in the body of the patient and when it gets into a healthy person the same variola disease is produced. That process is named sticking". He also wrote that smallpox can be eradicated which event happened in 1979 !

In 1838 Gebhardt Xavér Ferenc dealt also with variola. His opinion was that "... the cause of smallpox is an own sticker. The knowledge of medical doctors is unfounded about the nature and chemical characteristics of this sticker and its way of effect in a patient. That situation does not help the therapy". He already determined five characteristics of that sticker!

These opinions were important as the first human and animal pathogenic bacterium that is the B. anthracis was only verified in 1850 and the first virus was discovered only in 1892.

\section{Hoffner József tought experimental epidemiology}

Now we have to mention the name of Pápai Páriz Ferenc again who proposed to use animal test for diagnostic purpose in 1690 and the name of Fekés György who wrote about animal as well as self-experiments in 1787. Fekés tested the effectiveness of medicines in his experiments.

Between 1826-1841 Hoffner József thought the subject of Epidemic Maladies for medical and surgical students on Pest University. He explained that an epidemic disease was caused by sticking malady/morbus contagious/sickly product. During the disease sickly product had been created which could cause the same illness in the same species or at least a similar malady in a similar species of healthy animals. His opinion was that the infectious character of an illness could only be exactly verified, if it was injected into healthy animals. In spite of the before mentioned facts at present it is believed that R. Koch's postulatum is quite original idea.

Results of early microscopical studies performed by medical doctors

In our country the first article contained the results of microscopic examinations was published by Paterson Hain János from Eperjes in 1671. He studied vinegar flies and eggs. He discovered the protoplasm in the eggs and realized the effect of heat on the activity of larvae. When the temperature was increased their move became faster in the fluid. When the increase continued over a certain degree of heat they died (heat sterilization). In 1684 Spilenberger Dávid described the so called "snow insect" (Figure 5). Lenhossék József popularized the use of microscope. He showed animalcule and eggs of worms to the inquirers. Human dermatopathogenic fungi where observed by the Hungarian Gruby Dávid at Paris between 1841-1845. In the same time Láng Adolf Ferenc from Nyitra presented his similar results in 1845 at Pécs on a scientific meeting (Figure 6).

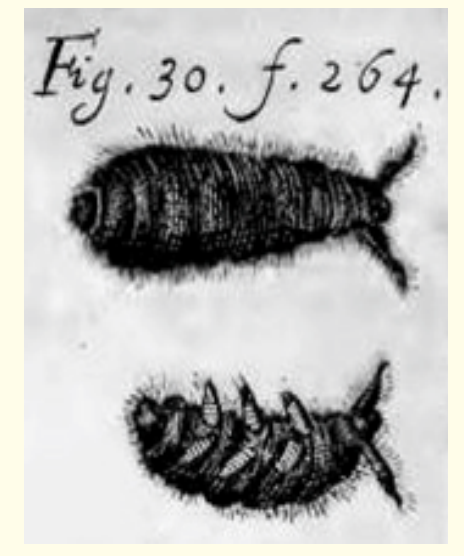

Figure 5: Snow insect.

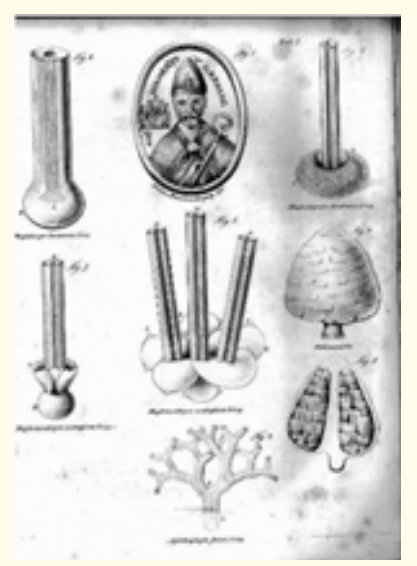

Figure 6: Láng's fungi.

Semmelweis Ignác Fülöp verified in 1847 that an "unknown decayed organic substance" caused puerperal fever. He realized that this substance was carried by the contaminated hands of health service personnel and students. He could stop the epidemics with using of chlorinated water for hand-wash - concept of antisepsis was borne. Schordann Zsigmond and Margó Tivadar examined protozoa on the Pest University before 1857. In 1863 at first Balogh Kálmán saw B. anthracis in microscopic preparation and he infected animals with this bacterium (Figure 7). He was the founder the exact microbiological laboratory diagnostic work in our country.

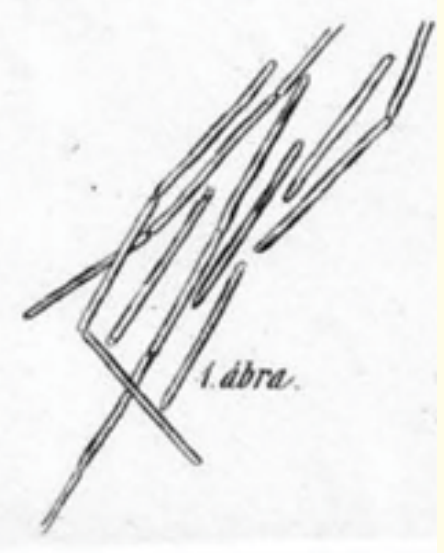

Figure 7: Balogh's B. anthracis.

Citation: Ralovich Béla. "Formation of Knowledge of Causes of Infectious Diseases and Development of Specific Prevention against them in Hungary from the Beginning till 1900". Acta Scientific Microbiology 1.4 (2018) 74-79. 
Formation of Knowledge of Causes of Infectious Diseases and Development of Specific Prevention against them in Hungary from the Beginning till 1900

Grossinger Keresztély János and the first microbiological chapter

Grossinger Keresztély János was a priest and an important scientist in the years of 1700 . He wrote an Encyclopaedia entitled "Universa Historia Physica..." which consists of more big volumes. In the Zoological volume he dealt with the veterinary science, too. In this book it can be read that "All living organisms have their own enemies as well as venoms. Insects attack animals internally and externally as for example: different species of Hippobosca, flukes, horse-flies, roundworms, tapeworms, leeches, ticks and wasps. It is also possible that animals on the pastures consume dangerous roots with which they get illnesses or even death". On the basis of our opinion he was the first person in our country who spoke about the macro- and micro material causes of animal diseases in united meaning. In the Vth Volume he dealt with the questions of the Plant Kingdom. He wrote about the role of microorganisms in the process of fermentation: "Micrographers teach from the vinegar: (R. Hooke, A. van Leeuwenhoek, J. Needham) all pungent vinegary substances are the consequence of worms." The importance of his thought was that in that period of time and later also fermentation was partly explained by Liebig's chemical theory. Finally Grossinger published the first independent Microbiological Chapter entitled "Micrographia" in his Encyclopaedia.

Immunizations against human infectious diseases

Raymann János Ádám studied a human variola epidemic in Eperjes District and published his observations in 1717. In 1721 he performed variolation between his two children and presented the usefulness of this immunization in a paper. In 1755 Weszprémi István wrote a book in London in which immunization against plague was proposed. His idea was not successful that time. Jenner's method (1796) was first applied in Sopron at 1801. Schraud Ferenc as chief medical officer proposed general immunization of our population against variola in 1804 and also decided to organize main Immunization Stations in Buda, Pest, Kassa, Gyula, Pozsony and Zágráb. His efforts were not successful that time. Latter Bossányi András establised an Immunization Station near Rókus Hospital at Pest around 1810. In 1824 Gebhardt Xavér Ferenc organized Smallpox Immunization Institute on Pest University which became Central Immunization Institute in 1850. That was the first human Virological Laboratory on the Pest University. Smallpox vaccination was ordered to be obligatory in 1812 but the final solution was only born in 1887 when the revaccination became obligatory. At Miskolc District Katona Mihály immunized children with the discharge of measles patient in 1842 with good result but his observations were not accepted. In 1886 Pécsi Dani organized the first private Institution for production of smallpox vaccine at Túrkeve. After Pasteur's announcement (1885) Hőgyes Endre developed his own vaccine against rabies and started to use it in 1895 with success. Before that the Pasteur's vaccine had already been applied from 1890 when Hőgyes organized a Pasteur Institute at Budapest University and later a Pasteur Hospital, too, where his vaccine was prepared and the patients suspected to rabies were immunized. In 1889 a Bacteriological Laboratorium was opened for the Office of Medical Officer of Budapest to perform cholera and water examinations. In 1893 the Hungarian Royal State Bacteriological Institute was organized for human and veterinary purposes where Preisz Hugó started to produce immune serum to diphtheria in 1895 and later to prepare tuberculin and mallein, too. Also in 1893 the Minister of Interior opened the Bacteriological Laboratorium of Ministry of Interior to help the protection against cholera and latter tuberculosis as well as to solve other public health problems.

\section{Immunization of animals}

As to the protection against variola Count Festetics György of Keszthely urged to perform variolation not only of sheep but also human beings in 1795. In 1803 Oeffner József who was a teacher on Keszthely Georgicon wrote a book entitled "Injection of variola into sheep". In this book it can be read that in 1795 when Chancellor Hoffman observed that even the best medicines which were used to treat sheep did not stop slaughtering of the animals by variola then they started to immunize the ewes". The Keszthely experiments were successful. In $1804 \mathrm{G}$. Sick who was a German professor published a book "About sheep variola and its injection" in which it was written that ovination was first performed in the Hungatian Holics around 1780. Süle Sándor wrote the history of Keszthely Georgicon in 1967. He reported that on Georgicon a Lamb Injection Institute existed before 1817. That was the first veterinary immuization institute in our country which was known in Vienna, too. In 1822 Nagyváthy János also dealt with ovinatio. He wrote that this immunization was widely used in the big aristocratic farms but he was not sure whether this practice was useful. In 1839 Havas Ignác who was a county medical officer published that he immunized oxen against rinderpest with good results. Almost in the same time Zlamál Vilmos the chif veterinary officer did the same experiments in another part of our country but this disease was eradicated by keeping of very serious veterinary measures. After Pasteur's experiments (1881) our experts invited him to present effectiveness of his vaccine against anthrax still in the same year and in 1887 that of the vaccine to swine erysipelas, too. After these successful experiments regular active immunization of animals has started. In 1882 Azary Ákos and his coworker immunized against Peripneumonia contagiosa.

Lipthay István worked out the legal base of obligatory immunization of animals in 1888. Use of mallein and tuberculin has started at the end of the XIXth century.

Diseases of plants and opinion of Frankovith Gergely about rust

Rust was that disease of plant which was first mentioned in both "Vienna-Codex" and "Apor-Codex" in the $2^{\text {nd }}$ half of the XVth century A.C. in Hungary. In 1576 Szikszai Fabricius Balázs wrote about illness of vine. Mélius Juhász Péter published about parasitic fungi and moss of trees as well as the preparation of wine. Perhaps that was the first food-technological description in our country in 
1578 in spite of the fact that our people have already consumed milk products, alcoholic drinks, bread and other doughs as well as sausages earlier than 1000 A.C.

In 1588 Frankovith Gergely wrote from agricultural catastrophies in his book. It can be read in it that "...if clouds go there to where God wants because of sins of people rust, cold and hail cause losses there. He thought "... that the situation was the same in case of plague and other kind of diseases, too". That might be the first occasion when an expert thought that rust spread with air like plague.

Lippay János was the teacher of plant-protection and foodpreservation

In 1662 Lippay János published a calendar in which he spoke from mouldy of grain, the black rust and dealt with the vine and wines. Protection of plants as well as preservation of foodstuffs (salting and smoking of meat, fermentation of cabbage and so one) were also mentioned. Later he wrote three books, too. In the book entitled "Kitchen garden" the following sentence can be found: “... the thunderstorms (hail, cold, hot, shower, hoarfrost, rust, black rust and other troubles originated from sky) could cause great problems..." as the rust substance was in the air "... which if fell on leafs, flowers and fruits then they became burned. Other dangers also existed which were named similarly rust or black rust.... He dealt with the fruit-trees and bushes and their diseases as well as their protection, too. The ways of food preservation and the use of "acid leaven" were also mentioned. His books as textbooks had been used for more than 100 years and their content was the base not only of our teaching of agriculture as well as horticulture but also that of food-production and preservation, too.

\section{Results of microscopic plant examinations}

In 1799 Csokonai Vitéz Mihály studied moulds with a magnifier and wrote their picture. In 1806 Kováts Antal dealt with the possible fruit-tree pathogenic effect of moulds, black rust, rust, floury, living plants and microscopic infusoria. In the next year came out the book of Diószegi Sámuel and Fazekas Mihály. They wrote from Mucors which could damage foodstuffs and fruits. Fejér Elek summarized in a modern form his knowledge connected with different diseases of plants caused by fungi in 1815 . Also in the same year Pethe Ferenc wrote that the cause of black rust was "... a fungus which could only be seen with a magnifier and propagated very rapidly by seeds... and spread fast from plant to plant". In 1847 Tognio Lajos published the results of his study. He examined sick potatoes and saw "microscopic fungi" but was not able to verify their pathogenic role. Microscopic picture of mildew fungi was presented by Bugát Pál on a meeting held at the Hungarian Academy of Sciences in 1853. Exact microscopic and latter cultural examination have started in the last third part of the XIXth century in Hungary on agriculture, horticulture and food production and in the same time the scientific plant protection was also born (Deininger Imre, Linhardt György, Istvánffi Gyula, Doby Géza, Horváth Géza and so on).

\section{Summary}

During our history the following terms were used as the cause of an infectious illness besides the will of God: the first was Egyedúti Gergely's death of sky and latter Frankovith Gergely's sticker, poison and pestiferous substance. Since their opinions the next names can be read in publications: animalcule, chaotica, fungus, hostes, infusoria, insect, living plant, noxia, poison, plague, sickly product, sticker contagium, seed, unknown decayed organic substance, vermiculus, virus and so on. These terms were applied not only before 1850 when the role of B. anthracis was verified but after it also for years.

\section{Bibliography}

1. Ralovich Béla. "Data to the history of teaching and research of microbiology". Balatoberény, Volume I (2011).

2. Ralovich Béla. "Data to the history of teaching and research of microbiology”. Balatonberény, Volume II (2014).

3. Ralovich Béla. "Data to the history of teaching and research of microbiology”. Balatonberény, Volume III (2018).

\section{Volume 1 Issue 4 April 2018 (c) All rights are reserved by Ralovich Béla.}

